\title{
The Autonomous Communities in the Law on the State Foreign Service and Action
}

\author{
Rafael GARCÍA PÉREZ*
}

\begin{abstract}
In March 2014 came into force the Law on the State Foreign Service and Action (LAESE). It is a legislative initiative aimed to modernize and coordinate Spain's foreign politics. It was sponsored by the current Government of the Popular Party and has been approved only with the support of the same parliamentary group. The main objective of the law, to guarantee the principle of the state action unity, has put the Autonomous Communities in the middle of the political debate. Most of the critics done by the opposing parties have been focused on this aspect remarking its "re-centralizing" character. Therefore, it is worth to debate if the law shortens the autonomic competences in foreign issues. The present article analyses the treatment received by the Autonomous Communities in the text of the above mentioned law. I conclude that it does not cut autonomic competences in foreign issues, while identifying several debilities that put in doubt the effectiveness that the new law can reach.
\end{abstract}

Keywords: Foreign action - foreign policy - autonomous communities - Spain

\section{INTRODUCTION}

The current Spanish Government (Popular Party) has defined the reordering of diplomacy and foreign projection of the states, one of the goals of the Ministry of Foreign Affairs and Cooperation (MFAC), through two relevant laws: the Law on the State Foreign Service and Action ${ }^{\mathrm{I}}$ and the Law of Treaties and Other International Agreements, ${ }^{2}$ as well as the adoption of the new Regulation of the Diplomatic Corps. ${ }^{3}$ Moreover, MFAC adopted for the first time a Strategy of Foreign Action, ${ }^{4}$ which should be approved by the Parliament.

The Law on the State Foreign Service and Action (from now on LAESE, from the Spanish acronym) has been approved by the Parliament on March 20I4. It is a long text, with sixty Articles, sixteen additional provisions, plus six final provisions. It was designed to adapt to the changes occurring in the international system in the last decades and to the institutional coordinates in which the state's foreign policy operates (EU, NATO, etc.). Circumstances different from the one sat the time of the approval of the Constitution of 1978. In particular, this law recognizes the complexity arising from the territorial organization of the state in Autonomies and the participation of diverse subjects in foreign action. All of which justifies the need for this new rule.

\footnotetext{
* Associate Professor of International Relations, University of Santiago de Compostela. Email: rafael.garcia@usc.es.

Ley 2/20I4 de la Acción y del Servicio Exterior del Estado (25 March 20I4), text available at <http://www.boe.es/boe/dias/2014/03/26/pdfs/BOE-A-2014-3248.pdf>, accessed I5 October 2014.

I2I/000072 Proyecto de Ley de Tratados y otros Acuerdos Internacionales (November 5, 20I3), text available at <http://www.congreso.es/public_oficiales/Lio/CONG/BOCG/A/BOCG-IO-A-72-I-Ci.PDF>, accessed I5 October 2014.

3 The legislation is very old: Organic Rules of the Diplomatic Corps (Decree of July 15, I955); Regime for Promotion and Provision of Diplomatic Posts (Royal Decree 3033/1976, 3 December; amended by Royal Decree 674/1993, 7 May).

4 Adopted by the Council of Ministers on 3 October 2014.
} 
Overall, the law has some weaknesses and technical legal issues that have not been changed in its main features during its passage through Parliament. Deficiencies already highlighted by the Council of State, ${ }^{5}$ as well as by some analysts. ${ }^{6}$

However, the entry into force of LAESE represents a significant step in the management and organization of the Spanish foreign policy. The main goal of the law is to preserve the unity of the State's foreign action. The State's Foreign Affairs is conceived by the law as an orderly set of actions undertaken by different subjects under the principle of unity in foreign action and subject to the guidelines, goals and objectives set by the Government. However, the regulation established by LAESE is as clarifying as necessary, both with regard to the bodies of the Central State Administration and the Autonomous Communities. This has enabled the involvement of foreign policy in the territorial debate currently live in Spain following the Catalan independent process, turning the law into a weapon among political groups. Thus, the debate is focused on the role given to the Autonomous Communities by the new law. Nevertheless, it is disqualified by nationalist parties which consider it another instrument of the "re-centralizing offensive" promoted by the Government. ${ }^{7}$

Therefore, it is questionable whether the new law meets that objective and whether autonomic powers in this area have been cut. The point of view advocated in these pages is contrary to this perspective. The law does not suppress or limit autonomic powers previously recognized by successive decisions of the Constitutional Court (CC) and the Statutes of Autonomy. Those certainly have a higher legal status and its provisions cannot be changed by this procedure. The law does not

5 Dictamen del Consejo de Estado sobre el Anteproyecto de Ley de Acción y del Servicio Exterior del Estado (394/2013) (30 May2013) text available at <www.boe.es/buscar/doc.php?coleccion=consejo_estado\&id=2013-394\#top >, accessed I5 October 2014. The main technical failures revealed by the State Council highlighted the unnecessary repetitions regarding rule in force, or that it is unfair that the bill regulates aspects of Foreign Service's functioning more typical of a regulation than a law of its range.

6 A. Mangas Martín, Comparecencia ante la Comisión de Asuntos Exteriores del Congreso de los Diputados para informar en relación con el Proyecto de Ley de la Acción y del Servicio Exterior del Estado (17.9.2013) available at $<$ www.congreso.es/portal/page/portal/Congreso/GenericPopUp?next_page=/wc/verEmisionAudiovisual\&idOrgano=302\&i $\mathrm{d}$ Sesion $=\mathrm{I} 8 \& \mathrm{fecha}=\mathrm{I} 7 / 09 / 2013 \&$ secuencia $=54634 \mathrm{I}$ \&legislatura $=\mathrm{IO}>$, accessed 15 October 2014; "El mundo de las apariencias", $\mathrm{El}$ Mundo (I3.II.2013). X. PONS RAFOLS, "El proyecto de ley de la acción y del servicio exterior del Estado: algunas reflexiones". Revista Catalana de Derecho Público / gencat blog (4.II.20I3) text available at <http://blocs.gencat.cat/blocs/AppPHP/eapc-rcdp/2013/i1/o4/el-proyecto-de-ley-de-la-accion-y-del-servicio-exterior-delestado-algunas-reflexiones-\%E2\%80\%93-xavier-pons/>, accessed i5 October 2014. J. A. YTURRIAGA, "Necesidad de una Ley del Servicio Exterior", Voz Populi. com (3.4.2013) text available at <http://vozpopuli.com/blogs/2408-jose-a-yturriaganecesidad-de-una-ley-del-servicio-exterior>, accessed 15 October 2014; "Luces y sombras de la Ley de Acción y Servicio Exterior", Voz Populi. com (I4.4.20I4) text available at <http://vozpopuli.com/blogs/4282-jose-a-yturriaga-luces-y-sombrasde-la-ley-de-accion-y-servicio-exterior>, accessed is October 20I4. R. García Pérez, "La proyección internacional de las Comunidades Autónomas en la Ley de la Acción y del Servicio Exterior del Estado (LAESE): Autonomía territorial y unidad de acción de la política exterior”, 27 Revista Electrónica de Estudios Internacionales (2014) text available at <http://www.reei.org/index.php/revista/num27/articulos/proyeccion-internacional-comunidades-autonomas-ley-accionservicio-exterior-estado-laese-autonomia-territorial-unidad-accion-politica-exterior $>$, accessed is October 2014.

7 I. Goikoetxeta, "El cancerbero anacrónico", Deia (I.2.2013) text available at <www.deia.com/2013/o2/or/opinion/tribunaabierta/el-cancerbero-anacronico>, accessed Is October 20I4. The author is a board member of the PNV. On criticis from the Generalitat vid.: "El Govern detecta en un mes 9 leyes recentralizadoras del PP”, El Periódico (Io.2.2014) text available at <www.elperiodico.com/es/noticias/politica/govern-detecta-mes-leyes-recentralizadoras-del-308688I>, accessed I5 October 2014 . 
amend or alter these competences, nor does it create new ones for the benefit of the Government.It merely reaffirms those that have previously been conferred by the Constitution and recognized by constitutional jurisprudence. However, the treatment given to the Autonomous Communities' foreign action is not the most successful and, above all, is dominated by a regulatory tone that expresses a deep institutional distrust of the government towards the autonomies. It is the imperfect manner in which this issue has been regulated which questions the effectiveness of the law and its application.

The new law recognizes the foreign policy powers inherent to the competences of the Autonomous Communities. At the same time, it reaffirms the state's ability to regulate the mechanisms for the coordination of that activity on state's foreign policy, in order to achieve consistency. To this end, it subjects the action of the Autonomous Communities to the guiding principles of the state's foreign policy and, in particular, to the principle of unity in foreign action (Articles I.I and 3). More specifically, it establishes that the foreign action of the Autonomous Communities must adequate to the "guidelines, goals and objectives of the foreign policy set by the government" (Article II.I). It is the way that "adequacy" is made that arises institutional distrust towards the Autonomous Communities. But if the purpose of the law was to reaffirm the principle of unity in foreign action, the LAESE casts doubt on the ability to achieve it. If unity in foreign action is a praise worthy and necessary mean to improve the decreasing foreign projection of Spain in the last decade, the threats that undermine it have multiple origins and are not confined to the Autonomous Communities. They also arise from within the government, whose action tends to be increasingly compartmentalized. It would have been necessary to reinforce the authority and hierarchy of the MFAC in this sensitive dimension. An issue that the law does not contemplate.

With regard to the Autonomous Communities, the law establishes the subjection of the latter's action to the guiding principles of the state's Foreign Affairs and, in particular, to the principle of unity in foreign action (Article I.I and 3). Moreover, it defines the obligation to notify the MFAC of the proposed trips, visits, exchanges and actions of the chairmen and members of their Governing Councils outside the scope of the European Union (Article 5.2); as well as, to inform the Government of the establishment of offices for foreign promotion (Article I2); or the enactment by the Government of measures and guidelines that regulate and coordinate the Autonomous Communities' foreign activities (Article II.2). All these provisions respect the jurisprudence of the Constitutional Court, ${ }^{8}$ which has been recognized by the State Council in its Opinion. ${ }^{9}$

Where then would lie the foreseeable conflict over which the spokespersons of the opposition groups incessantly insisted during the debate of the bill in Parliament? The core of the problem lies in the fact that the law lays its foundations in the notion of "foreign action", a denomination not used in the Constitution or by the CC in its judgments. Therefore, the legal text bears an unnecessary conceptual confusion which deserves some comments.

8 In particular the following judgments: STC 165/1994; SSTC 31/2010 y 80/2012. Overall, according to the High Court, the Autonomous Communities, as local authorities endowed with political autonomy, cannot act as sovereign international subjects, although they can perform actions that have connection to the foreign sphere, as long as they may be necessary or convenient for the exercise of their autonomous powers and not influence the state's foreign policy.

9 Dictamen supra No. 5, at V.3.A (i). 
THE STATE'S INTERNATIONAL RELATIONS, GOVERNMENT FOREIGN POLICY AND STATE AND AUTONOMOUS COMMUNITIES FOREIGN AFFAIRS

Informally, in the political and academic language used in Spain,the expression "foreign action" has been adopted to refer to activities with international projection undertaken by the autonomous governments. This allows differentiating them from the "foreign policy" which, as has been repeated, is an exclusive competence of the Government. The concept of "para-diplomacy" whose common meaning would be a synonym for autonomous foreign action, has not achieved in Spain the acceptance it had in other countries that have adopted it as the standard to refer to the international relations of sub-state entities.

Moreover, in more rigorous terms, the Constitutional Court has employed in its judgments the term "international relations" to refer to the exclusive competence of the state in the matter (STC 165/1994). It is understood as the relations between Spain and other independent and sovereign states and governmental International Organizations, governed by general International Law, as defined by Article 96.I of the Constitution, and by the treaties and agreements in force for Spain. At the bottom, the "core" of this competence would be represented by the capacity to conclude international treaties (ius contrabendi), and the state's foreign representation (ius legationis), as well as the creation of international obligations and the international responsibility of the state.

From this situation, however, the LAESE adopted the term "foreign policy" as a doctrinal foundation, giving it a new meaning. Thus, it is stated in such broad terms that only adds confusion to a situation that demanded clarity and simplification. Therefore, Article I.I. establishes that the purpose of the law is to "regulate the state's Foreign Action". It then defines in its Article I.2 the fundamental concepts in the following terms:

For the purpose of this law the following terms mean:

a) Foreign Policy: the set of decisions and actions of the Government in its relations with other actors in the international scene, in order to define, promote, develop and defend the values and interests of Spain abroad.

b) State Foreign Action: the ordered set of actions that the constitutional bodies, public administration, and dependent organizations, entities and institutions abroad, in the exercise of their respective powers, developed in accordance with the principles set out by this law, in particular the unity in foreign action. While observing and subject to the guidelines, goals and objectives set by the Government in the exercise of its powers to guide foreign policy.

The distinction between "foreign policy" and "foreign action" stated by this Article, whose consequences are defined throughout the text, is tremendously confusing, both in concept and in its practical application. This definition is also excessive, to the extent that its only basis seems to be the interpretation by LAESE of Article 97 of the Constitution.

The State Council, in its Opinion cited above, ${ }^{\text {Io }}$ highlighted the "catch-all" trend used in the wording of Article I.2 that does not correlate with the interpretation expressed by the CC through its judgments, which "is excessive and needs to be bounded". The Opinion states that this universalistic view of foreign action "may be excessive and difficult to deal in reality", due to the fact that it

\footnotetext{
ro Dictamen, supra No. 5, at V.3.b (ii).
} 
includes within itself the actions of all dependent constitutional bodies, public administrations, agencies, entities and institutions, including government agencies, public corporations, public foundations and associated entities.

Without doubt, the aim of fixing this differentiation is the Government's desire to assert its legitimate authority to conduct foreign policy. Thus preserving the principle of unity in foreign action. But in doing so it creates an artificial distinction denying, in fact, that the Autonomous Communities may carry out a "foreign action" with a political dimension, setting their own goals, objectives and priorities. It is true that the CC has recognized in its ruling on the Statute of Autonomy of Catalonia (STC $3 \mathrm{I} / 20 \mathrm{IO}$ ) that among the state powers it has "the possibility to establish measures to regulate and coordinate the Autonomous Communities' activities with foreign projection, to prevent or rectify eventual damage on the management and implementation of foreign policy, exclusive to the state" (Paragraph 125). However, as highlighted by Professor Pons Rafols, denying the political nature of the autonomic foreign action, as done by the LAESE, constitutes a "jump which is excessive". ${ }^{\text {II }}$

In any case, the lack of clarity between what is part of the "foreign policy" and what is proper to the "foreign action" is evident throughout the Articles. Although separately stated the "principles and objectives" of the first (Article 2) and the "guiding principles" of the second (Article 3), the Government is in an indeterminate position. On the one hand, it is responsible to conduct foreign policy, and, on the other, a "subject" more, among many others, on foreign action (Article 6). When the instruments of planning, monitoring and coordination are identified from what, in principle, should be the foreign policy, and which are fully adopted by the government, the LAESE elects to use the term "foreign action" both to call the Strategy and the Annual Report (Articles 35 and 37).

The law establishes a conceptual difference between foreign policy and foreign action particularly contrived and confusing in its results. And if in doctrinal terms it is debatable, it is manifestly inappropriate as a referent to regulate the institutional relations between the Government and the Autonomous Communities. The exclusive powers of the state against the Autonomous Communities in international relations cannot include any provision concerning foreign action, determining on the distribution of powers in this matter. It would have been necessary to have specified with greater rigor and clarity both concepts during the parliamentary procedure.

\section{THE LIMITS OF THE AUTONOMOUS COMMUNITIES FOREIGN ACTION WITHIN LAESE}

The LAESE imposes restrictions to the foreign action of the Autonomous Communities which includes the provisions of the Constitution and the jurisprudence of the Constitutional Court:

The actions undertaken in the exercise of Foreign Action may not include, in any case, the assumption of state representation abroad, the conclusion of international treaties with other states or international organizations, the generation of obligations or responsibilities internationally due to the state or the interference with the Foreign Policy run by the Government. In any case, the Government is responsible for establishing measures and guidelines that regulate and coordinate activities outside the Autonomous

\footnotetext{
II Pons Rafols, supra No. 6.
} 
Communities and Entities that make up the Local Administration, in order to ensure compliance with the provisions of this law. [Article Ir.3].

The practical implementation of these limitations is discussed below.

\section{(I) The Subjection of the Autonomous Foreign Action to the "planning tools" of the Government}

The conceptual confusion dealt with in the previous section is evident in Article I4 of the LAESE. This Article is devoted to the "areas of the state's Foreign Affairs and its relation to Foreign Policy". Its paragraph I establishes that:

The Government, through the Ministry of Foreign Affairs and Cooperation, under the powers conferred upon the law and in the manner provided in the planning instruments by it regulated, will ensure that the Foreign Action in its various fields, including those listed in Articles 15-32 of this law, will preferentially target the areas or countries identified as priorities for the fulfilment of the Foreign Policy goals.

It may also encourage the action of the organs, subjects and actors in any other area deemed appropriate to achieve the purposes of the Foreign Policy.

That is, the priorities for meeting the objectives of foreign policy will be set through the planning instruments of foreign action foreseen by the law (the Strategy and Annual Plan): ${ }^{12}$ Foreign Action Strategy and Annual Report on Foreign Action. Can these documents subordinate foreign actions outside the Autonomous Communities as intended?

The foreign action of the Autonomous Communities must abide by the guidelines, goals and objectives of the foreign policy set by the Government in accordance with Article 97 of the Constitution. As well as any other that proceeds from the exercise of the exclusive jurisdiction of the state in international relations. That is reaffirmed by Article I4.I. Yet, another issue is the adequacy to the planning instruments of Foreign Action (Article II.2), so far non-existent. Its wording assumes exclusively the role of the government, although it,

where appropriate, shall collect and integrate proposals for foreign action of the constitutional bodies, the Autonomous Communities and Cities and Local Authorities. The non-integration of the proposals by the bodies and entities mentioned in the previous paragraph must be substantiated and be based on the adequacy of the guidelines, goals and objectives of the foreign policy set by the Government (Article $34 \cdot 3)^{13}$

The content of the Foreign Action Strategy is not sufficiently detailed in the text of the law which can lead to an overreaching by the Government in its powers. That is indicated by the State Council in its Opinion by stating that,

the performance of the Autonomous Communities must not be conditioned by any content of those instruments, but only limited to those defining guidelines for action characteristic of the state's foreign policy or included in the field of Spain's international relations. ${ }^{14}$

In theory, this aspect of the LAESE predicts possible conflicts when it is applied in practice.

2 LAESE (Article 34 - 40).

r3 In parliamentary procedure the wording of this section was modified to include the government's obligation to "seek" the proposals submitted by the Autonomous Communities and respond in a reasoned way if it does not accept them.

i4 Dictamen, supra No.5, at V.3.A (i). 


\section{(2) Conclusion of Administrative and Non-Normative International Agreements by the Autonomous Communities}

The LAESE briefly deals with an issue that the current government considers crucial to the autonomic involvement within the state's foreign action. That is the conclusion of "international agreements"s by the Autonomous Communities. Misnomer that was criticized by professor Mangas in her appearance before the Congress. ${ }^{16}$

This is an activity that has dramatically proliferated. According to data provided by the Minister of Foreign Affairs and Cooperation during his speech in the parliamentary debate of the bill, during the period between 2008 and 2012, the Autonomous Communities had 166 offices abroad, had made 93I trips abroad and signed 277 memoranda of understanding. ${ }^{17}$ This "huge mess", in the words of the minister, is extended to the Central State Administration which during the same period had made more than seven hundred trips abroad and signed an uncountable number of agreements. But this calculation only reflects the most important agreements and is not an exhaustive survey. Actually, there are no comprehensive data on these activities. Information that is not provided by all public administrations, which is indicative of the need to exercise some oversight by the Ministry. ${ }^{18}$

Although in their original jurisdictional powers the ability to sign such documents did not feature, in practice the Autonomous Communities have been able to sign an endless number of agreements of all kinds: conventions, protocols, joint statements, Memorandum of Understanding, etc. They have common features in general: ${ }^{19}$ pledging only the local authorities that conclude it; no legal effect; do not generate enforceable international obligations to the state and, in general, do not assume the exercise of sovereignty. In practice, these agreements have been divided into three categories so far (except for the border cooperation agreements): ${ }^{20}$ a) those signed with other sub-state entities; b) agreements signed with intergovernmental organizations with international legal personality; and, c) agreements concluded with states, because sometimes there is no other similar local authority with which to sign and, for reasons of national law, the agreement must be signed by the Government. Until now there was no regulation on the procedure to be followed, except in border cooperation agreements. However, the common practice in the cases $b$ and $c$, was that the Autonomous Communities communicated in advance, to the Ministry of Foreign Affairs and

is S. Beltrán García, Los acuerdos exteriores de las Comunidades Autónomas españolas. Marco jurídico actual y perspectivas de fututo, (Universitat Autònoma de Barcelona - Institut d'Estudis Autonòmics, Barcelona, 200I).

16 Mangas, supra No. 6.

${ }_{17}$ "Intervención del Sr. Ministro de Asuntos Exteriores y de Cooperación ante el Pleno para presentar el proyecto de ley de referencia" (I5 October 2013), text available at < http://www.exteriores.gob.es/Portal/es/SalaDePrensa/ComparecenciasParlamentarias/Documents/20131015_ActasComparec enciaMAEC_LASEE.pdf>, accessed I5 October 20I4. "La acción exterior de las autonomías deberá seguir directrices del Gobierno", El País (19.2.2013). It does not include the 24 border cooperation agreements signed with neighboring regions of France and Portugal.

I8 R. García Pérez, "La acción exterior de las Comunidades Autónomas", in J. Ma BENEYTO and J.C. PEREIRA (dirs.), Política exterior española: un balance de futuro (Biblioteca Nueva, Madrid, 20II), vol.2, 715.

19 C. Fernández Casadevante, La acción exterior de las Comunidades Autónomas. Balance de una práctica consolidada (Dilex, Madrid, 200I) I78.

20 C. Colino, La acción internacional de las comunidades autónomas y su participación en la política exterior española (Fundación Alternativas, Madrid, 2007) 40. 
Cooperation, the content of the agreement intended to sign, so that it could analyse if there was any objectionable aspect. This procedure is modified by the new law in its Article Ir.4:

The Autonomous Communities, the Autonomous Cities and Entities that make up the Local Administration may conclude administrative international agreements on the execution and prosecution of an international treaty, when determined by the treaty itself, by vesting it with the power to sign it and when it focuses on matters within its competence. They may also conclude non-regulatory agreements with similar bodies in other subjects of International Law on matters within its competence, not legally binding to those who subscribe it.

The Ministry of Foreign Affairs and Cooperation will inform in advance and in accordance with the directive of the state law governing its conclusion, of the administrative international agreements and those non-abiding that these Administrations wish to conclude with administrative authorities or bodies subject to International Law. To this end, it will receive the report from the competent ministerial departments by reason of the subject and, in any case, from the Ministry of Finance and Public Administrations.

As shown, the MFAC is responsible for writing a mandatory preliminary report on all kinds of international agreements that the Autonomous Communities wish to conclude. This has been written in the final version of the law despite the criticisms made by the opposition groups in Parliament which considered this new requirement as the imposition of the Government's safeguard. However, the aforementioned Article II.4 refers to the "state law" in charge of regulating these issues. This is the Law on Treaties and Other International Agreements. ${ }^{21}$ A legislative initiative also promoted by the government in the current legislature and complementary to LAESE. This law is currently under parliamentary procedure, and clarifies the content of some Articles of the first. In particular with regard to the autonomic level.

The Treaties bill recognizes the right of the Autonomous Communities to conclude, within their competence, international agreements classified into two categories: "administrative international agreements" ${ }^{22}$ (Article 54), those derived from the "execution and realization of an international treaty when the treaty itself so provides"; and "non-normative international agreements" ${ }_{23}$ (Article 55), those who "do not constitute a source of international obligations".

For the first category, the Treaties bill establishes a mechanism for previous control similar to the current one on agreements for cross-border cooperation which can be concluded between the Spanish Autonomous Communities and the Spanish local authorities with foreign territorial entities under the European Outline Convention on Transfrontier Co-operation between Territorial Communities or Authorities of May 21, 1980. The drafts of administrative international agreements must be submitted

${ }_{21}$ Vid. supra No. 2.

22 Article 2.b.: "«international administrative agreement»: agreement of international non-constitutive treaty character held by bodies, agencies or entities of a relevant international subject by reason of law. Its conclusion is provided for in the treaty that applies it. Its typical content is technical in nature whatever its denomination and it is governed by International Law. It is not an administrative international agreement the one concluded by those bodies, agencies or entities when it is governed by domestic law".

23 Article 2.c.: "«non-normative international agreement»: agreement of international non-constitutive treaty character nor administrative international agreement held by the state, the Government, agencies, and entities of the Central State Administration, the Autonomous Communities and the Cities of Ceuta and Melilla, the Local Authorities, public Universities and any other subjects of public law empowered to do so, which contains declarations of intent or establishes action commitments with political, technical or logistical character, and does not constitute a source of international obligations nor is it governed by International Law". 
before signing to the Ministry of Foreign Affairs and Cooperation, "to report by the International Legal Department on its nature, procedure and most suitable instrumentation under International Law" (Article 4I.I). In those cases involving financial commitments, the MFAC, before signing, sends it to the Ministry of Finance and Public Administrations to report (in both cases within a period of ten days) on the existence of budgetary funding for their prosecution. These agreements shall be published in the Official Journal (BOE in the Spanish acronym).

In the case of "non-normative international agreements" it is up to the legal services of the public agency that concludes it the responsibility to report if the project should be formalized as an international treaty or an administrative international agreement. It will also report on the capacity to conclude it and on how they fit the constitutional division of powers. In case it involves financial obligations they must have a report from the Ministry of Finance and Public Administrations (Article 47). The Autonomous Communities have autonomy to decide the method by which these agreements are formalized (Article 48).

If the text of the Treaties bill is finally adopted without changing these Articles, it could be argued that the government has taken the criticism voiced by the opposition groups who feared the exercise of a governmental previous control over the powers of the Autonomous Communities. The solution proposed by the government allows to exercise the oversight over the signature and content of these agreements. The text will then be sent to the MFAC for enrolment in a specific registration (Article 50). When proposed, together by the MFAC and the ministry competent in the matters of the agreement, the right to "take note of the conclusion of non-normative international agreements when its importance so warrants" is reserved (Article 48.2.).

The Treaties bill reaffirms the exclusive jurisdiction of the state to conclude international treaties, as the only sovereign subject recognized by International Law, which also regulates the autonomic participation in its conclusion. In its present form, the text does not alter the procedure hitherto: it establishes the obligation of the Government to inform the Autonomous Communities on the negotiation of treaties which affect its powers or are of their interest (Article 52). They may also request the Government to open negotiations to conclude treaties in areas within its jurisdiction (Article 5I). The novelty is that the government will reasonably respond to this request, following a proposal by the MFAC and the report of the Ministry of Finance and Public Administrations. The possibility for the Autonomous Communities to request the Government to be part of the Spanish delegation that negotiates an international treaty concerning their powers is also envisioned (Article 53). In this case the answer must be justified on the same terms as exposed.

Perhaps the main innovation is the creation of an inter-ministerial coordination Committee on treaties and other international agreements (Article 6). This Committee is responsible for enforcing the cooperation between the Central State Administration and the Autonomous Communities.

\section{(a) Official Trips Abroad of Autonomic Autborities}

The official trips abroad by the autonomic authorities are the most widespread autonomic activity abroad. These trips are justified by the most diverse reasons. A common denominator is the search for political relief and media attention sought by many politicians. Felipe González's government tried to 
regulate and coordinate these activities. ${ }^{24}$ But ended up giving up, ${ }^{25}$ failing to solve the problems of coordination, lack of information and competence abuses as exposed. ${ }^{26}$

To date, the Autonomous Communities have been able to have the support of the state's Foreign Service in their trips. To do so, the Technical Secretariat of the MFAC should be informed of the program of the visit, including the date of departure and return, the people who make up the delegation and the purpose of the trip. No further requirements.

Against this background one can understand the change, which is more in structure than in content, represented by what LAESE's Article 5.2. demands:

The constitutional bodies, the Autonomous Communities, the Autonomous Cities, the entities that make up the Local Administration and dependent agencies, entities and institutions should keep the Ministry of Foreign Affairs and Cooperation informed of the proposals on trips, visits, exchanges and performances with foreign outreach. So that this department can inform and, where appropriate, make recommendations based on the adequacy of the proposed action to the guidelines, goals and objectives of the Foreign Policy set by the Government and the planning instruments established by this law.

This obligation for the Autonomous Communities and Autonomous Cities to report includes the trips, visits, exchanges and actions of chairmen and members of the Government Councils, and shall not apply in the case of actions within the field of the European Union and trips or visits to its institutions.

The Ministry of Foreign Affairs and Cooperation shall notify the Finance and Public Administrations of the information received from the Autonomous Communities and entities in the Local Administration.

The text of this Article was amended on parliamentary procedures at the request of the PSOE, ${ }^{27}$ which reflected concerns rose by the Autonomous Communities, including those governed by the PP. In its final version the obligation to give prior notice of those autonomic actions performed within the scope of the EU has been excluded. For other trips abroad, the trips made by officials and senior officials from territorial administrations have also been excluded from this obligation. This is a sensible amendment that modifies a measure which, if implemented, would have complicated the autonomic foreign action without obtaining therefore a significant improvement in the unity in foreign action.

However, the Article adopted maintains a commanding tone that does not agree with the actual demands contained in the text. After all, those are limited to the obligation of the Autonomous Communities to inform the MFAC in advance of those trips in certain cases and for certain authorities. ${ }^{28}$ The fact that the Ministry may "report and, if necessary, issue reasoned recommendations"

24 The only previous rules on the subject were: Circular of the Technical Secretariat of the MAE (31.IO.1983) to the Delegates of the Government on trips and external contacts of the autonomic authorities; and Circular (I3.3.1984) to embassies and consulates abroad, on the same issue. None of them was published. A. RUÍZ ROBLEDO, "La actividad exterior de las Comunidades Autónomas en el segundo Estado Autonómico", 7I-72 UNED Revista de Derecho Político (2008) $48 \mathrm{I}-5 \mathrm{I} 3$, at 495 .

${ }_{25}$ This was highlighted by the Minister of Public Administration J. M. Eguiagaray in a report submitted to the Executive Committee of Autonomic Policy in the mid-nineties. Colino supra No. 20 at 34.

26 J. L. Pardo Cuerdo, La Acción exterior de las Comunidades Autónomas: teoría y práctica (MAE, Madrid, I995) (Colección Escuela Diplomática, No. I).

27 PSOE is the Spanish acronym for the Spanish Socialist Workers' Party.

28 In his parliamentary speech, the Minister Garcia-Margallo argued that the aim was "to instruct the ambassador to be made available" to the authorities conducting the visit and facilitate the efforts and support they need, given the lack of planning observed in many of these trips where autonomic delegations were not received by the authorities they wanted to visit. Vid. Supra No. 17 at 27. 
does not detract the discretional decision of the Autonomous Community to apply or not the ministerial recommendation, since the law does not (because it cannot do so since it is not subject to its authority) foresee any sanction or prohibition of the trip planned. So it does not seem that the LAESE will substantially change the habits and autonomic procedures followed so far, unless a spirit of collaboration and institutional loyalty, which is not created by the law, is collectively assumed.

\section{(b)Autonomic Representative Offices Abroad}

Something similar happens with the treatment given by the new law to the autonomic representative offices abroad, a subject dealt with in Article $12 .{ }^{29}$

The Autonomous Communities have established various types of offices abroad: permanent official delegations with representative functions abroad, journalistically called as "embassies"; and specialized sectorial offices, with duties of foreign promotion. Its different names and functions, and the fact that each autonomy uses different criteria for its calculation, makes it difficult to have a complete census of the total number. Thus, the frequent oscillations in the figures periodically offered.

The creation of the first autonomic representative office before the Communitarian authorities in Brussels sparked the first major jurisdictional conflict with the Government over this issue. It was resolved by the STC 165/1994 mentioned above. It specified that the Autonomous Communities may establish offices abroad to exercise their autonomic functions, not granting them an international status nor state functions. This was enshrined in the Law on Organization and Functioning of the Central State Administration, ${ }^{30}$ promoting a real emergence of these centers. In 2013 , there were 166 autonomic offices throughout 36 countries (Table I).

\begin{tabular}{|l|c|c|c|}
\hline AUTONOMOUS COMMUNITY & 2010 & 2013 & Variation \\
\hline Andalusia & 22 & I9 & -3 \\
\hline Aragon & 5 & 4 & $-\mathrm{I}$ \\
\hline Asturias & $\mathrm{I} 3$ & 4 & -9 \\
\hline Balearic Islands & 2 & $\mathrm{I}$ & $-\mathrm{I}$ \\
\hline Basque Country & $\mathrm{I} 2$ & $\mathrm{I} 4$ & +2 \\
\hline
\end{tabular}

29 The text of Article 12.of the Offices of the Autonomous Communities and Cities abroad reads as follows:

"I. The Autonomous Communities and Autonomous Cities will inform the Government of the establishment of offices for foreign promotion, prior to its opening. The Ministry of Foreign Affairs and Cooperation will inform of the proposal, according to the guidelines, goals and objectives of the Foreign Policy, of the Foreign Action Strategy, and in particular, according to the principle of unity in foreign action.

2. The Ministry of Finance and Public Administrations will inform of this proposal in accordance with the principle of efficiency in the management of public resources as well as from the perspective of its relevance to the jurisdictional order.

3. In the case of offices dedicated to trade promotion, the report of the Ministry of Economy and Competitiveness will also be sought.

4. The Government will promote the installation of these offices within the premises of the state's Foreign Service, when allowed by the space available in that department. Only if such installation does not imply its integration in the state's Foreign Service, nor application to such offices of international law, especially those comprised in the Vienna Conventions on diplomatic and consular relations".

30 Article 36.7. Ley 6/1997de Organización y Funcionamiento de la Administración General del Estado (I4.4.1997) text available at <https://www.boe.es/boe/dias/1997/04/15/pdfs/Air755-II773.pdf >, accessed I5 October 2014. 


\begin{tabular}{|l|c|c|c|}
\hline Canary Islands & 8 & 8 & - \\
\hline Cantabria & 4 & 4 & - \\
\hline Castile - La Mancha & 2 & 3 & + I \\
\hline Castile and León & 5 & II & +6 \\
\hline Catalonia & 48 & 4 I & -6 \\
\hline Ceuta & - & - & - \\
\hline Community of Madrid & II & IO & - I \\
\hline Extremadura & 4 & 6 & +2 \\
\hline Galicia & I2 & 7 & -5 \\
\hline La Rioja & 2 & 2 & - \\
\hline Melilla & - & - & - \\
\hline Murcia & 8 & 8 & - \\
\hline Navarre & 5 & 4 & - I \\
\hline Valencian Community & 23 & I9 & -4 \\
\hline TOTAL & I88 & I66 & -22 \\
\hline
\end{tabular}

Table I: Autonomic Offices Abroad (source: MAEC ${ }^{31}$ )

It should be noted that the offices abroad must be authorized and recognized by the state where they are established. Authorization subject to the previous agreement with the official representation of the Spanish state, which is the embassy. At the end of the day, the autonomic officials are private citizens, for all purposes, in the country of destination without diplomatic status to enable them to carry out their representation functions. Only cooperation and good understanding with the embassy can improve the conditions in which they can perform those functions. So far this has given those offices a certain consensus on the foreign policy of the government through the embassy.

At the beginning of its term, the current government offered the Autonomous Communities the possibility of integrating in the offices of diplomatic missions the foreign offices of the Autonomous Communities. ${ }^{32}$ The procedure for the voluntary integration of these autonomic offices consists of two phases: first the signing of a "Protocol of Cooperation" (memorandum of understanding between each interested Autonomous Community and the relevant Ministry) and then the signing of a "Collaboration Agreement", ${ }_{33}$ which establishes the details.

31 Data for 2013 are from the MFAC: "La acción exterior de las autonomías deberá seguir directrices del Gobierno", El País (19.2.2013) text available at <http://politica.elpais.com/politica/2013/02/18/actualidad/1361211063_672270.html> accessed I5 October 2014. Data for 2010 were offered, in Parliament, by the Vice-president, third in Government, M. Chaves: "El PP mantiene abiertas 64 'embajadas autonómicas', Público (31.5.20I0) text available at <http://www.publico.es/espana/316718/elpp-mantiene-abiertas-64-embajadas-autonomicas $>$ accessed 15 October 2014.

32 The Autonomous Communities bear the costs of services and supplies and the cost of the space used. Comisión para la Reforma de las Administraciones Públicas (CORA): Informe (Ministerio de Hacienda y Administraciones Públicas, Madrid, 2013), 96, text available at <www.lamoncloa.gob.es/docs/refc/pdf/refc20130621e_I.pdf >, accessed I5 October 2013.

33 The MFAC has formalized agreements of this kind with La Rioja, Castile and León, Asturias and Navarre for their integration into the EU-REPER. And the Ministry of Economy with the Autonomous Communities of Valencia, Galicia, Murcia, Cantabria, Andalusia and Castile and León. The agreements with Castile-La Mancha, Aragon, Canary Islands, the Community of Madrid, Extremadura and La Rioja are still pending formalization. Vid. Supra No. 3I, at 97. 


\section{FINAL REMARKS}

Given the political scene lived in Spain in the last years, where it is so difficult to reach agreements among the main political forces, the Ministry of García-Margallo has managed to develop a Law on Foreign Action which has some strengths but also significant weaknesses that have been exposed in the preceding pages. Perhaps, the most serious of them all, for reflecting conceptual problems that affect the whole of the law, is the confusing way in which the state's foreign action is conceived, the scope of which fails to distinguish it from foreign policy itself. It also reflects short comings, such as cooperation for development, which are not foreseen by the law; and greater absences, as in the case of European politics, which should have a specific and more detailed treatment, given the jurisdictional relevance of the Autonomous Communities in this area.

The LAESE aims to coordinate and provide unity to the state's foreign action. In that sense it subjects the Autonomous Communities to the guidelines of the foreign policy defined by the Government. Moreover, their actions cannot invade the exclusive competence of the state in issues such as the conclusion of treaties, foreign representation and international responsibility. Nothing controversial nor novel although it is done in an imperative tone that contradicts the spirit of conciliation repeatedly stated by the Government and reflects the tough tone of the Spanish political action in recent times.

A separate issue is the Foreign Action Strategy whose content is not precisely defined by the law. It seems disproportionate to pretend to subordinate autonomic foreign action, depriving it of its political dimension and subjecting it to a governmental policy document.

With regard to the autonomic offices abroad and the official trips abroad, the LAESE merely imposes as mandatory to previously inform the government, through the presentation of a report by the MFAC. The Autonomous Communities are not obliged to follow these recommendations, which hardly helps to change the practice so far.

The LAESE highlights the constraints posed by trying to manage political and institutional problems through legislative initiatives based on a transient absolute parliamentary majority, without having a climate of prior dialogue between the main political forces and without the required collaboration between the various institutions. The process of parliamentary procedure should have been used to correct the deficiencies and gaps present in the bill preventing, in any case, to turn the management of the state's foreign action into a scenario that represents the territorial tensions in the country. Given the disagreement expressed by the opposition groups in Parliament, and the obvious deficiencies of the text, it is risky to expect that this law will achieve the objectives for which it was enacted. 